Portland State University

PDXScholar

Institute for Sustainable Solutions Publications

and Presentations

Institute for Sustainable Solutions

$1-1-2010$

\title{
A Virtual Visit to a Sustainable 2050
}

Robert Costanza

Portland State University

Follow this and additional works at: https://pdxscholar.library.pdx.edu/iss_pub

Part of the Sustainability Commons

Let us know how access to this document benefits you.

\section{Citation Details}

Costanza, R. (2010). A Virtual Visit to a Sustainable 2050. Solutions Journal, 1(6), 9-11.

This Article is brought to you for free and open access. It has been accepted for inclusion in Institute for Sustainable Solutions Publications and Presentations by an authorized administrator of PDXScholar. Please contact us if we can make this document more accessible: pdxscholar@pdx.edu. 


\section{A Virtual Visit to a Sustainable 2050}

\section{by Robert Costanza}

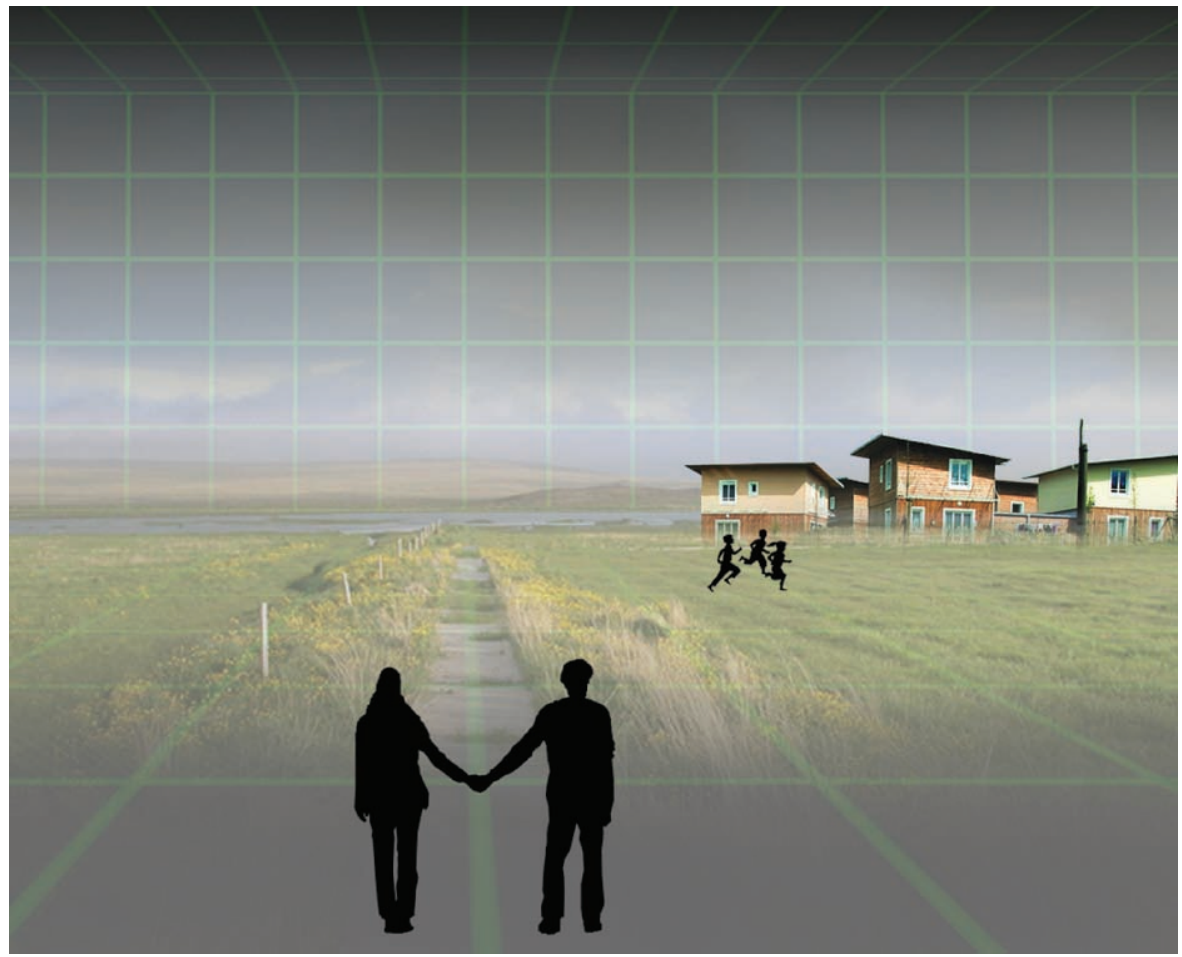

Guy Derry for Solutions

A new very advanced virtual reality system just released reminds me of a holodeck on Star Trek. The "reality" it simulates is generated by a cross between a real-time systems simulation model of the biophysical environment, an agentbased personality simulator (a super-Sims), and an advanced "future search" consensus-building system. Participants can create a future world that represents their overlapping hopes and dreams, tempered by the constraints of human nature and biophysical reality. Assumptions about these constraints are programmed in (by mutual agreement of the participants) at the start of the session. For our session, we agreed on a set of what we considered to be realistic assumptions, both about people and the rest of the world, that embodied the latest scientific research findings. We didn't assume any major technological breakthroughs but rather assumed historical rates of technical change. We also assumed that people would not be fundamentally any different than they are now but that the environments (both physical and social) that they lived in would be very different.

Without you actually using the system and visiting the future virtual world yourself, it is, of course, difficult for me to describe. Like a real world, our simulated future was rich in detail. What follows is an attempt to convey some of that richness and texture by describing my own experiences in our simulated future world. These experiences covered a lot of different ground, but, taken together, they allow a fairly clear image of the future world we created. We agreed on a rough target date of 2050.

What really struck me about this future world was the overriding sense of calm and peacefulness but without any tinge of boredom. The best way to describe it is the difference between adolescence and mature adulthood. Our current society is adolescent-fixated on physical growth, changing so fast it is difficult to adjust-frenetic, self-absorbed, self-conscious, irresponsible, insecure, taking. Our envisioned future world was mature - not growing physically and therefore able to focus on development-improving quality not quantity, secure, invested in long-term relationships, responsible, nurturing, giving. For example, the average work week was 20 hours but the distinction between work, learning, and leisure had become pretty blurred, so it's difficult to make this comparison directly, as you'll see. But the bottom line is that life was not so hectic and people had more time for their families, each other, and the things that really interested them. That's where the calm and peacefulness came from. Since people could pursue what really interested them, they were not bored and their mental health and sense of satisfaction with life were excellent.

Susan was the first person I met in the simulation. I'd wandered into a coffee shop near what was almost certainly a university campus (lattes were still on the menu). We struck up a casual conversation about the weather (very warm), and I innocently asked her, "What do you do?" I got a very quizzical expression. I quickly explained that I was visiting from another country and just wanted to know what kind of work she did. She said, "Oh, you must be on a travel sabbatical." (I later found out this was a common practice in 2050 , where 
people exchange places for periods of a month to a year instead of taking vacations in the traditional sense.) She told me she worked as a researcher and teacher at the university, but it quickly became apparent that people in 2050 didn't define themselves by their jobs to the extent they do today and, at the same time, that their lives and their work were more fully integrated. For example, Susan explained that all of her current research projects were also courses that she was teaching. Teaching had become much more problem based-learning by doingrather than lecture based. Students and faculty participated in research projects together, and everyone learned while attacking real problems. When I asked what department Susan was in at the university, I got that quizzical expression again. She explained that the university had become transdisciplinary. There were research (and learning) centers focused on particular problems, but the traditional academic departments had disappeared. She suggested that I come along to a seminar on the State of the World 2050 report that had just been released by the Worldwatch Institute.

As we walked through the campus, I noticed that the age distribution of the people we saw was much different than I'm used to seeing on university campuses. Instead of a mass of young faces punctuated by a few older professors, the population looked much more evenly spread over the full range of ages. Susan said that people in 2050 considered learning a lifelong activity and had the time to actually implement that idea.

The seminar room was packed, and we arrived just in time to get seats at the back as things got under way. I asked Susan how long the Worldwatch Institute had been around, and she said at least 70 years or so. It was one of the first NGOs (nongovernmental organizations) formed at the end of the twentieth century. Many of these had survived, grown, and diversified to the point of being equally if not more important than formal governments in the actual governance of society. They represented one of the many forms of the "strong democracy" that seemed to be the buzzword to describe the way society was now governed. More on that later.

The seminar began, and the speaker spent about an hour summarizing the report. It covered an awful lot of ground, and I started taking notes before I remembered that any notes I took would only be holograms that would disappear when I returned to the real world. These are some of the things I can remember:

- Global human population was stable at about 8 billion people. This was due to better education everywhere, excellent elder care at the community level so that people no longer thought they needed many children to take care of them in old age, and a tacit multicultural norm of "replacement only." There was still quite a bit of international migration but not so much as to stress national borders, and, in fact, national borders were now for the most part open.

- The "material throughput" of national and global economies was decreasing slightly but not nearly as fast as in the past (obviously the speaker thought we could do better here). At the same time, the QOL (quality of life) index was going up at about 2 percent per year on average. The QOL measure was assessed annually using a global Internet survey that asked people to rank how well their needs in nine key areas (subsistence, protection, affection, understanding, participation, leisure, creation, identity, and freedom) were being met. The United States ranked near the top in subsistence, protection, and freedom but was below average in the other areas. Its overall QOL rank fell somewhere just above the median (but this had been improving in recent years). The real efficiency of the economy was now computed as the ratio of QOL to material throughput, and this was also increasing.

- Gaps in income were decreasing both between countries and within countries, and this contributed to building strong social capital, the solution to many recalcitrant social problems, and increasing QOL without increasing material throughput.

- Global biodiversity was making a comeback. Since the human population had stabilized and throughput was decreasing, pressure on the environment had also stabilized and there were concerted and well-funded efforts to protect and enhance biodiversity.

- The biggest problem seemed to be dealing with the continuing effects of climate change. Global $\mathrm{CO}_{2}$ emissions were decreasing, but they had a long way to go before we were back to preindustrial levels. New Orleans had already disappeared and the Netherlands was under constant threat. But cautious optimism seemed to be the message here.

As we left the seminar, I asked Susan about the "strong democracy" concept that had been mentioned. The puzzled look again — where had I been? She said it was nothing really new, just the idea that everyone should participate directly in decision making at all levels rather than delegating that authority to elected representatives. When I expressed some skepticism that this could ever be practical, she 
just waved her hand and said, "Well look around-it is working." I never got the full answer, but I think it was a combination of people having more time for participation in politics, a better communications infrastructure that used the advanced version of the Internet they had by then, a deep culture of participation that was inculcated from a very young age, and the general maturity of the whole system that I mentioned before.

Susan invited me to come over for dinner and meet her husband and children. I gladly accepted this chance to see how domestic life worked in 2050. Her house was an easy so-minute bus ride and 5-minute walk from campus. It was clustered in a group of about 50 houses, along with some shops and small businesses, in what she referred to as a village (even though it was in a large urban area). The village shared common green space, gardens, bike and foot paths, and a few other resources. All transport within the village was by bike or foot. She explained that (like most villages) they used an internal LETS (laborequivalent trading system) to keep track of shared labor services. For example, if I spent some of my free time helping paint somebody's house, I would rack up "hours" that I could cash in to get help on some project of mine. Again, an overriding sense of calm and peacefulness pervaded the place (probably due to the lack of car noise-replaced by the sounds of birds chirping and children playing in the shared green space).

Susan's husband, Paul, and their two young daughters, Lisa and
Jennifer, shared a three-bedroom house that seemed to be about average by today's standards. In fact, Susan mentioned that the house had been originally built in 200I and retrofitted with the latest energy technologies so that it actually produced more electricity than it consumed. By making almost all buildings part of the energy-production grid, and drastically reducing the need for transportation, the whole economy was now able to run on renewable, sustainable resources.

Susan had to back up Paul in his decision not to let the girls spend the night at a friend's, and I inspected the books on their bookshelf while the girls threw a tantrum over this injustice (some things never change). After things settled down, we all sat down to dinner. I explained to the girls that I was on a "travel sabbatical" and was wondering what people did for fun in this part of the world. The answers were not dissimilar from what you might hear today, including movies, dances, parties, and concerts. The only differences I noticed were that most of the activities mentioned were social-people seemed to spend more time interacting with each other than staying at home watching TV—and "shopping at the mall" did not come up as a favorite activity, even among teenage girls. In fact, I think malls had all but disappearedreplaced by a combination of Internet shopping, local village shops, and a general lowering of consumption levels. The dinner, for example, was almost all food grown in the village gardens (the avid gardeners in the village were racking up a lot of LETS hours), and the rest came from the village shop, which was a five-minute walk from the house. I asked if there were any big problems in the village and got a litany of typical neighbor complaints-one was drinking too much, another had too many loud parties, and so on. But in general, these problems were solved by talking with people at village events rather than by calling the police (come to think of it, I don't think I saw a policeman or heard a siren the whole time I was there). People hadn't changed, it seemed, but the "system" had-and this allowed them to solve their inevitable problems in more mature, friendly, and productive ways.

As I left Susan and Paul's house, I was thinking that it just couldn't be this simple. There must be a catch. Wouldn't all this social serenity require a suppression of creativity and initiative? How could people be happy and productive in an economy that wasn't growing? But after thinking it through, it was clear that, in fact, it could easily work. Just like an individual organism that goes through a stage of early rapid physical growth followed by later "development" without further growth, a whole socioeconomic system could do the same. And from personal experience, I can attest that the teenage years are often difficult and not as happy as later years when growth has stopped and one can concentrate on the joys of development. I found that I really liked being an adult in this adult society. And as I was thinking this, the simulation ended and I returned to the present. $\mathbf{S}$ 